\title{
The Dynamite Club
}


This page intentionally left blank 


\title{
The Dynamite Club
}

How a Bombing in Fin-de-Siècle Paris

Ignited the Age of Modern Terror

\section{John Merriman}

With a New Preface

\author{
Yale \\ UNIVERSITY \\ PRESS
}

NEW HAVEN \& LONDON 
Published with assistance from the Kingsley Trust Association Publication Fund established by the Scroll and Key Society of Yale College.

First published in paperback in 2016 by Yale University Press.

Originally published in hardcover in 2009 by Houghton Mifflin Harcourt.

Preface to the Paperback Edition copyright (@) 2016 by John Merriman. Copyright $\odot 2009$ by John Merriman.

All rights reserved.

This book may not be reproduced, in whole or in part, including illustrations, in any form (beyond that copying permitted by Sections 107 and 108 of the

U.S. Copyright Law and except by reviewers for the public press), without written permission from the publishers.

Yale University Press books may be purchased in quantity for educational, business, or promotional use. For information, please e-mail sales.press@yale.edu (U.S. office) or sales@yaleup.co.uk (U.K. office).

Book design by Robert Overholtzer.

Printed in the United States of America.

Library of Congress Control Number: 2015951237

ISBN 978-0-300-21792-6 (pbk.: alk. paper)

A catalogue record for this book is available from the British Library.

This paper meets the requirements of ANSI/NISO Z39.48-1992 (Permanence of Paper). 
For VICTORIA JOHNSON 
This page intentionally left blank 